\title{
О СЕМАНТИЦИ КАТЕГОРИЈЕ БРОЈА У ОКВИРУ ГЛАГОЛСКЕ СИСТЕМЕ СРПСКОХРВАТСКОГ ЈЕЗИКА
}

1. Категорији броја се при описивању српскохрватског глаголског система у познатим граматикама ${ }^{1}$ поклања прилично мало пажње. Међутим, ова категорија је са граматичко-семантичког гледишта из више разлога интересантна и за учење српскохрватског језика за странце није небитна.

а. Категорија броја се јавља код свих финитних и инфинитних глаголских облика, и то код свих финитних а из области инфинитних код партиципа, када - по традицији - искључујемо глаголске именице из глаголског система.

b. Код финитних и инфинитних облика граматичко значење броја има различит статус у односу на своју самосталност.

с. Код финитних облика је граматичка категорија броја везана са категоријом лица и (код неких сложених облика) Genus nomini, код инфинитних облика само ca Genus nomini.

d. Као битно граматичко обележје финитних облика глагола категорија броја (у вези са категоријом лица) има важне синтактичке функције које разликују српскохрватски (заједно с другим словенским језицима) од других европских језика.

1 Уп. нпр. М. Стевановић, Савремени српскохрватски језик II, Београд 1979; Т. Маретић, Граматика хрватскога или српскога книжевног језика, Загреб 1963; С. Тежак, С. Бабић, Преглед граматике хрватскосрпског језика, Загреб 1966; Брабец, Храсте, Живковић, Граматика хрватскога или српскога језика, Загреб 1958; Е. Барић и др., Приручна граматика хрватскога книжевног језика, Загреб 1979; М. С. Лалевић, Синтакса српскохрватскога книжевног језика, Београд 1962; А. Белић, Историја српскохрватског језика, књ. II, св. 2: Речи са конјугацијом, Београд 1962; али и нпр.: М. Rešetar, Elementar grammatik der serbokroatischen Sprache, Halle (Saale) 1959; V. Frančić, Gramatyka opisowa języka serbochorwackiego, Warszawa 1956. 
е. У вези са категоријом лица категорија броја има важне прагматичко-стилистичке функције које су од значаја за савладавање српскохрватског језика².

На неке проблеме који су везани са овим констатацијама односи се следеће наше излагање.

2.1. Полазећи од познатог схватања да постоје два принципијелно различита типа (морфолошких) граматичких значења, и то самостална, тј. независна од контекста облика речи који изражава одговарајуће граматичко значење (овом облику инхерентно значење), и несамостална, тј. зависна од контекста облика речи који изражава ово граматичко значење ${ }^{3}$, може се пре свега поставити питање о уврштењу значења броја у ову класификацију.

Претпоставка за одговор на ово питање је став према различитом уврштењу глагола од стране југословенских сербокроатиста као самосталне или несамосталне врсте речи. А. Белић, после њега М. Стевановић и др. полазе од тога да је глагол у српскохрватском (и не само у српскохрватском) несамостална врста речи, пошто, како Белић, очигледно се ослањајући на схватања W. Wundta, тврди да су самосталне само „именичке речи" које се могу јављати (?) изван реченице. У односу на глагол тврди се: „глагол као такав служи ближем одређивању какве самосталне речи”, и „У реченици је глагол ... несумњиво потчињен субјекту...”

Финитни облици глагола који се употребљавају без субјекта се, пошто су сами „потпуна реченица”, интерпретирају као несамостални. Тако настаје необично схватање да финитне глаголске облике, управо пошто могу самостално конституисати једну реченицу, треба уврстити као облике несамосталне врсте речи ${ }^{4}$.

М. Стевановић у својој великој граматици показује како ова Белићева аргументација води закључцима који су важни за нашу проблематику: „За субјект смо рекли да је то једини независни члан реченице... Од њега је, дакако, зависан и члан реченице којим се субјекту што прип-

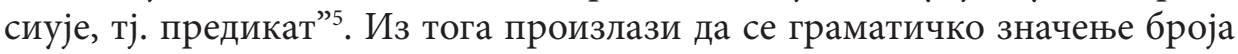

2 Уп. H. Walter, Zur Problematik der Kategorie Person des Verbs im Bulgarischen und Deutschen, Linguistische Arbeitsberichte 20 (1978), S. 95 ff.

3 Уп.: Autorenkollektiv unter Leitung von N. Ju Švedova, Грамматика современного русского литературного языка, Москва 1970, 302.

${ }^{4}$ А. Белић, О језичкој природи и језичком развитку, I књига, Београд 1958, 11. И схватања младограматичара као нпр. Х. Паула су вероватно имала утицај на ово гледиште.

${ }^{5}$ М. Стевановић, нав. дело, 34. 
(лица и рода) код финитног глагола сматра зависним, као и род и број, одн. и падеж придева у атрибутској функцији.

Управо постојање бесубјектних реченица са финитним обликом глагола као језгром и односи конгруенције у двочланој реченици у односу на број између субјекатске фразе и глагола, показују да овај став противуречи стварности. Стварно, постојање реченица као „То морам да кажем”, „Треба да напишемо како је било”, „Само повећаваш конфузију”, „Моје честитање, ако само хоћете да примите од мене”, „Мора да се поздрави”, „Неће ни косом да махну”, даје оправдање да се категорија броја код финитних облика интерпретира као независна, јер ти су облици сами у стању да сигнализирају значење броја. Због тога и А. В. Исаченко о везама од личних заменица у функцији субјекта и финитних глаголских облика говори као о плеонастичким везама ${ }^{7}$. Српскохрватски језик претежно избегава такве плеоназме. У томе се он разликује од језика као што су немачки и руски. Различита учестаност јављања једночланих реченица овога типа у 1. и 2. лицу с једне, а у 3. лицу с друге стране, може се објаснити тиме што се 3. лице односи на појаве које се налазе изван комуникационих партнера, које су до њиховог означења непознате или има анафорски карактер и, по правилу, треба бирати између више познатих субјеката који потенцијално могу да се јаве у финитном облику, што такође захтева означавање субјекта (углавном уз помоћ анафорске заменице):

Иво и Јана су се вратили у град и она је одмах била код своје мајке.

Као доказ за то да је значење броја финитних глаголских облика независно од субјекта у реченици, може служити чињеници да се облици множине не спајају само са субјектима који се налазе у множини, нпр. „Писали смо и Давидовић и ја.” „Он и Јоцо упуте се озбиљним корацима с рукама на леђима.” „Твој пријатељ и ви сте свему криви.” ${ }^{8}$ То значи, у овим случајевима се значење „рашчлањености”, које је за множину битно одређујуће, на неки начин рашчлањава у појединачне елементе у субјекатској фрази која припада облику множине глагола (уп. 3.3.). У случајевима конгруенције по броју између придева и именица оваква појава није могућа: „ „лепи мушкарац и жена”, где би се „лепи” односило на обе именице, није по норми.

6 Примери по Стевановићу, М. Стевановић, исто, 36, и Приручна граматикa, 317.

A. V. Isačenko, Die russische Sprache der Gegenwart, Teil I, Halle (Saale) 1968’ 274.

8 Уп. М. Стевановић, нав. дело, 125. 
Дакле, оправдано је гледати на питање самосталности значења броја код финитног глагола у смислу аутора „Приручне граматике” који одређују категорију броја и као глаголску категорију. ${ }^{9}$

2.2. Исто питање, наиме, да ли се значење броја, које је у овом случају увек повезано ca Genus nomini-значењем, преноси „споља”, требало би поставити и за партиципе. Овде одговор зависи очигледно од тога да ли су партиципи саставни део перифрастичких глаголских облика или се употребљавају атрибутивно. Полазећи од 2.1. и сматрајући те облике као перфекте индикатива или партиципски пасив перифрастичким облицима, како је обично у српскохрватској стручној литератури (граматици), долази се до закључка да је значење броја и овде независно. Када, међутим, партиципи имају придевску функцију, тј. када се употребљавају самостално (не као саставни део једног опширнијег глаголског облика), морамо сматрати њихово значење броја зависним од именице уз коју стоје.

3.1. Значење броја финитних глаголских облика које се не може посматрати одвојено од значења лица, због чега је и оправдано говорити о категорији лица/броја ${ }^{10}$, у међународној лингвистици је спорно. То није толико везано са обележјем „џ рашчлањеност” које се у широким круговима признаје као одлучујуће за избор једнине или множине, већ са питањем како да се значење лица/броја у познатих шест комбинација $(1,2$, 3. лице једн. и множ.) опише. Свакако, може се констатовати да само обележје „рашчлањеност” није довољно за граматичко описивање. Као пример овде може служити једна комбинација обележја (+ сигнализирање учешћа говорника у радњи коју означује глагол $)+(+ \text { рашчлањеност })^{11}$ како би се доделила 1. лицу множине, један начин описивања значења лица/броја који се налази и (углавном имплицитно) у српскохрватским граматикама. Много повољније нам се чини описивање могућих денотатских односа облика лица/броја који одговарају језичком узусу и одступањима од тога која се јављају и која служе одређеним стилистичко-прагматичким циљевима. При једном оваквом описивању јављају се интересантни погледи на компликованост односа субјеката изражених радњи који су садржани у завршецима лица/броја код глагола.

9 Уп. Приручна граматика..., 147.

10 УП. Н. Walter, Die komplexe Kategorie Person/Numerus als Kategorie mehrerer Wortarten in südslawischen Sprachen; Studia gramatyczne V, 1982, S. $133 \mathrm{ff}$.

11 УП. D. Müller, Zur Beschreibung kategorialer Bedeutungen aus translatienslingustischer Sicht; Zeitschrift für Slawistik XXVIII (1983), S. 38. 


\section{2. Облици једнине:}

Овде је пре свега реч о облицима 1, 2. и 3. лица једнине. За описивање значења лица сматрамо следећа обележја:

Л (лице), Г (говорник), А (адресат), ПК (предмет комуникације), Сп (специфицираност).

Обележје „СП” је потребно за описивање облика 3. лица и неких значења облика 1. и 2. лица, јер они преносе глаголску радњу, по правилу, на специфичне, али и на неспецифициране субјекте. (Под субјектом се овде подразумева логички субјекат који, међутим, није исто што и агенс). Ово обележје се пре свега односи на /+ ПК/, па онда на /+ A/, ако садржи комбинацију обележја /- ПК/ и /- A/, на /+ Г/, уз присуство /- Г/ на /+ Л/. У истој хијерархији дејствује обележје /P/ (рашчлањеност). Како се у даљем излагању види, ово обележје због тога није у свим комбинацијама обележја облика множине позитивно маркирано. За поменуте облике једнине добијамо следећа маркирања поменутих обележја:

\section{Узорак 1}

\begin{tabular}{|c|c|c|c|c|c|c|}
\hline Облик & Л & $\Gamma$ & A & ПК & $\mathrm{P}$ & $\mathrm{C} \Pi$ \\
\hline 1. једн. & + & + & - & - & - & + \\
\hline 2. једн. & + & - & + & - & - & + \\
\hline 3. једн. ${ }^{1}$ & + & - & - & + & - & + \\
\hline 3. једн. ${ }^{2}$ & - & - & - & + & - & + \\
\hline
\end{tabular}

Раздвајање 3. лица једнине потребно је због употребе обележја Л. Уписивања у узорак одговарају нормалној (нетранспонираној) употреби ових облика у реченицама као:

(1) Пишем писмо.

(2) Пишем писмо.

(3) (Човек)

$$
\text { (Машина) }\} \text { пише лепо. }
$$

\section{3. Облици множине:}

То су облици 1, 2. и 3. лица множине. Ове облике карактерише делом знатна полисемија. Тако могу да се изражавају од облика 2. лица множине у нетранспонираној употреби следећа значења која се као субјекат односе на глаголску радњу: „ти и други” (2. множ. $\left.{ }^{1}\right)$, „ти и други” (2. множ. $\left.{ }^{2}\right)$, „група адресата” (2. множ. $\left.{ }^{3}\right)$. Још више значења се јавља код 
облика 1. лица множине: ,ја и други” (1. множ. $\left.{ }^{1}\right)$, „ја и други” (1. множ.. ${ }^{2}$, „ја и ти” (1. множ. $\left.{ }^{3}\right)$, „ја и 2. множ. ${ }^{1 ”}\left(1\right.$. множ. $\left.{ }^{4}\right)$, „ја и 2. множ..$^{\prime \prime}\left(1\right.$. множ. $\left.{ }^{5}\right)$, „ја и 2. множ." (1. множ. $\left.{ }^{6}\right)$. Полисемија 3. лица множине приоизлази из два различита маркирања обележја Л.

Појединачно из излагања произлазе следећа обележја уписана у наш узорак:

Узорак 2

\begin{tabular}{|c|c|c|c|c|c|c|}
\hline Облик & Л & $\Gamma$ & A & ПК & $\mathrm{P}$ & Сп \\
\hline 1. множ. ${ }^{1}$ & + & + & - & + & + & + \\
\hline 1. множ. ${ }^{2}$ & + & + & - & + & - & + \\
\hline 1. множ. ${ }^{3}$ & + & + & + & - & - & + \\
\hline 1. множ. ${ }^{4}$ & + & + & + & + & + & + \\
\hline 1. множ. ${ }^{5}$ & + & + & + & + & - & + \\
\hline 1. множ. ${ }^{6}$ & + & + & + & - & + & + \\
\hline 2. множ. ${ }^{1}$ & + & - & + & + & + & + \\
\hline 2. множ. ${ }^{2}$ & + & - & + & + & - & + \\
\hline 2. множ. ${ }^{3}$ & + & - & + & - & + & + \\
\hline 3. множ. ${ }^{1}$ & + & - & - & + & + & + \\
\hline 3. множ. ${ }^{2}$ & - & - & - & + & + & + \\
\hline
\end{tabular}

Ови уноси одражавају нормалну употребу облика лица/броја множине као у следећим реченицама:

(4) Данас идемо у биоскоп.

(5) Да ли путујете за Берлин?

(6) (Ученици)

(Машине) $\}$ пишу лепо.

Негативно маркирање Р код 1. множ. ${ }^{2}, 1$. множ. ${ }^{3}, 1$. множ. $^{5}, 2$. множ. ${ }^{2}$ не значи да у укупном комплексу обележја недостаје рашчлањеност која је типична за множину, јер помоћу позитивног маркирања Г и ПК, Г и А, Г, А и ПК као и А и ПК рашчлањеност постаје видљива, која је с једне стране конкретнија, а с друге стране се налази на другом нивоу него она коју симболизира Р. Да је означимо са Р'. P' је она рашчлањеност у зна- 
чењу облика множине финитног глагола која може да се експлицитно изрази у њима додељеним субјектима, како смо изложили под 2.1.

4.1. Комплекси обележја које обухватају узорак 1 и узорак 2 показују код 3. лица једнине и множине и 1. и 2. лица множине полисемију која се не може свести на транспозицију. Ми ћемо поћи од тога да транспозиција постоји онда када су позитивно маркирана обележја од наведених комплекса обележја која одговарају узуелној стилистичко-прагматички неутралној употреби негативно маркирана, или обрнуто, тј. када се јављају маркирања-одступања. Код оваквих одступања најчешће је стилистичко или прагматичко маркирање.

4.2. Транспозиција у области броја/лица која се редовно третира у свим граматикама, и која је веома важна за практично савладавање језика - представља такозвани облик учтивости, тј. употреба 2. лица множине за изражавање комплекса обележја за који је облик 2. лица једнине типичан, везан са једним прагматичким комплексом обележја који садржи обележја као „дистантност”, „формално” и евентуално друга, која, међутим, нећемо овде опширно испитивати и излагати:

Узорак 3

\begin{tabular}{ccccccc}
\hline & Л & Г & А & ПК & Р & Сп \\
\hline 1 & + & - & + & $\ominus$ & $\ominus$ & + \\
\hline 2 & + & - & + & $\ominus$ & - & + \\
\hline 3 & + & - & + & - & $\ominus$ & + \\
\hline
\end{tabular}

У узорку 3 редови 1-3 служе поређењу са три нормална (без одступања) комплекса обележја 2. лица множине из узорка 2. Маркирања која одступају од тамошњих уписивања означена су кругом. Види се да код „облика учтивости” има одступања не само у односу на обележје „рашчлањеност” него и у односу на „ПК”, што је још један доказ за то да одвојено третирање броја и лица финитних облика глагола не узима у обзир важне везе.

4.3. Једна транспозиција у области категорије лица/броја која је позната у славистичком истраживању граматике - јесте такозвана „уопштенолична” употреба 2. лица једнине. Овај се облик употребљава са личном заменицом или без ње - у овим случајевима да би се изразило да се глаголска радња односи на неспецифицирани број лица која играју улогу субјекта. Са стилистичког гледишта са овом транспозицијом ве- 
зана је припадност стилу свакидашњице, а са прагматичког гледишта маркирање са „дистантност”. Узорак 4 показује одговарајући комплекс обележја са одступањима од 2. лица једнине која су уписана у узорку 1.

Узорак 4

\begin{tabular}{cccccc}
\hline л & Г & А & ПК & Р & Сп \\
\hline+ & - & $\ominus$ & + & $\oplus$ & $\ominus$ \\
\hline
\end{tabular}

Нпр.: Никад не знаш шта ће бити.

Прагматичко-стилистичко маркирање се осећа у поређењу са неутралним конструкцијама типа „Никад се не зна шта ће бити”.

4.4. Интересантна је такође транспозитивна употреба 3. лица множине која се обично назива „неодређено лично”. Одступање у односу на комплекс обележја од 3. множ. ${ }^{1}$ (у узорку 2) се само тиче обележја „Сп”, јер се глаголска радња овде такође односи на неспецифицирану количину субјеката који су лица. Разлика се према такозваној „уопштеноличној” употреби 2. лица једнине, дакле, састоји пре свега у мањем одступању од неутралне употребе. Због тога, можда, при томе, прагматички чиниоци нису од битног значаја, већ стилистички чиниоци, јер ова употреба облика 3. лица множине могућа је, очигледно, само у свакодневној језичкој употреби. Поређење са конструкцијом трпног стања која је стилистички неутрална то може доказати. Треба и споменути да, како се чини, постоји разлика између „уопштеноличне употребе” 2. лица једнине и „неодређеноличне употребе” 3. лица множине утолико, уколико последња уз истовремену употребу личне заменице није могућа.

Узорак 5

\begin{tabular}{cccccc}
\hline Л & $\Gamma$ & А & ПК & Р & СП \\
\hline+ & - & - & + & + & $\ominus$ \\
\hline
\end{tabular}

Нпр.: Тамо сада ваде мрки угаљ.

4.5. Што се тиче транспозитивне употребе у области категорије лица/броја, интересантна је и такозвана „множина скромности” (pluralis modestiae), тј. употреба 1. лица множине уместо 1. лица једнине из прагматичких разлога, пре свега, због велике полисемије облика 1. лица мно- 
жине коју смо констатовали. Како показује узорак 6, у коме редови 1-6 показују одступања од шест уноса који се односе на 1. лице множине у узорку 2, овде постоје одступања у маркирању три обележја, при чему се то не односи у сваком случају на „Р”.

Узорак 6

\begin{tabular}{ccccccc}
\hline & Л & $\Gamma$ & А & ПК & Р & СП \\
\hline 1 & + & + & - & $\ominus$ & $\ominus$ & + \\
\hline 2 & + & + & - & $\ominus$ & - & + \\
\hline 3 & + & + & $\ominus$ & - & - & + \\
\hline 4 & + & + & $\ominus$ & $\ominus$ & $\ominus$ & + \\
\hline 5 & + & + & $\ominus$ & $\ominus$ & - & + \\
\hline 6 & + & + & $\ominus$ & - & $\ominus$ & + \\
\hline
\end{tabular}

4.6. Пошто су код наше проблематике у питању радње које се односе на субјекте, наравно, оправдано је питање како може наш модел описати такозване „безличне облике” глагола. При овој употреби облика 3. лица једнине (и неутралног Genus nomini) субјект радње се елиминише, пошто говорник или није у стању или сматра да није релевантно именовати субјекат. Овде се убрајају конструкције као „Капље са тавана. Овде се не пуши. Сада се види добро. Грми. Једе ми се.” и многе друге. Помоћу наших обележја ова употреба би се овако описала:

\section{Узорак 7}

\begin{tabular}{ccccccc}
\hline & Л & $\Gamma$ & А & ПК & Р & СП \\
\hline 1 & $\ominus$ & - & - & $\ominus$ & - & $\ominus$ \\
\hline 2 & - & - & - & $\ominus$ & - & $\ominus$ \\
\hline
\end{tabular}

Редови 1 и 2 служе поређењу са уписивањима за 3. једн. ${ }^{1}$ и 3. једн. ${ }^{2}$ у узорку 1. Пошто се функција морфема лица/броја код глагола састоји управо у томе да сигнализирају податке о субјекту радње, оправдано је, по моме мишљењу, у овом случају у коме се ништа не исказује о субјекту радње, такође говорити о транспозицији, иако с тиме нису везане праг- 
матичко-стилистичке промене у поређењу са неутралном употребом. Интересантно је поређење степена апстракције при подацима лица/ броја у узорцима 4, 5 и 7 који показује да највећи степен апстракције представља такозвана „безлична” па онда „уопштенолична” а најнижи „неодређенолична” употреба одговарајућег облика.

5. Ова тема нашим излагањем, наравно, није исцрпена. У области финитних облика питање о даљим транспозицијама остаје отворено, нпр. код облика 1. лица једнине, 1. лица множине или 2. лица множине код којих је, чини се, могућа једна врста „уопштеноличне употребе” 12 .

Треба размотрити питање односа између категоријалног значења и начина употребе категорије лица/броја као што је Д. Милер учинио ${ }^{13}$, при чему би за значене броја било повољно обележје (позитивно или негативно маркирано) „Р” и „Р”” или нпр. за 1. лице позитивно маркирано обележје „Г”, за 2. лице позитивно маркирано обележје „А”. Наше излагање је, међутим, показало да су односи субјеката које изражавају одговарајући финитни облици толико компликовани, да би једно овакво одређење значења било исправно, али не би било довољно да се опише употреба. Други проблеми, као нпр. питања конгруенције при атрибутивној употреби партиципа прелазе оквир глаголског система. Све би то могло бити предмет даљег разматрања.

\footnotetext{
12 Уп. на цит. месту.

13 УП. на цит. месту.
} 